\title{
JAURES AND THE FORMULATION OF A SOCIALIST PEASANT POLICY, $1885-1898$
}

I.

On January 8,1893 , the voters in the second electoral district, Department of the Tarn, cast ballots in a partial election of more than local interest. The Marquis de Solages had resigned his seat in the Chamber of Deputies on the previous October i4 during the bitterness generated by the strike against his Carmaux coal company. The socialists of the district, at first with considerable hesitation 1 , nominated as their candidate Jean Jaurès, who had emerged as the outstanding champion of the Carmaux miners in 1892 . When he carried the election against Héral, his chief opponent, by a vote of 5317 to 4843 , it meant the return to Parliament of the man who emerged as one of the three most important socialists in the prewar Republic. ${ }^{2}$

But the victory of Jaurès was crucial for French socialism in another way, equally as important as the addition of a new, militant voice in the Chamber of Deputies. It meant the penetration of socialism into an essentially rural area of the Midi and the emergence of a leader closely associated with the life of peasant France. Alexandre Millerand, who had come recently to reformist socialism from the camp of radicalism, emphasized this theme on the eve of the victory: "The election of Jaurès will be even more important, since the socialist

1 Zévaès, A., Jaurès, Paris I95 I, p. 58. Jules Guesde, the chief Marxist in France and leader of the Parti ouvrier français, mixed enthusiasm with considerable reserve in writing of this selection: "We count on citizen Jaurès to justify the hopes of the ex-strikers of Carmaux and to go to the Palais-Bourbon... in accord with our program." Le Socialiste, December II, I892. There was still doubt as to the socialist sincerity of Jaurès.

2 The other two would certainly be Jules Guesde, who founded the Marxist Parti ourrier frangais in 1880 , and Edouard Vaillant, who founded the Blanquist Comité révolutionnaire central in 1881. Jean-Louis-Marie Jaurès was born in Castres, Departement of the Tarn, on September 3, 1859, and was assassinated in Paris on the eve of war, July 31, 1914. In his crowded lifetime he was philosopher, historian, deputy, socialist leader, founder and editor of L'Humanité. The best biography is the latest: Auclair, Marcelle, La Vie de Jean Jaurès (Paris, 1954). Also useful are Zévaès, op. cit., and Rappoport, Charles, Jean Jaurès (Paris, 1915). 
candidate will be elected for the first time by toilers of the field as well as workers of the city." 1

After his victory, Jaurès was quick to bring out this implication. The rural population, he explained, far from enjoying the prosperity and stability attributed to it in popular mythology, ${ }^{2}$ was beset with very real and serious difficulties. Small proprietors and tenants had to endure excessive land taxes, indebtedness to moneylenders, high interest rates for credit, and harsh terms set by middlemen in the marketing process; as for agricultural labourers, they were subject to the miserable working conditions of long hours and dismally low wages. ${ }^{3}$ In their discontent with the present and their hope for the future, the peasants were now turning to socialism. "Through you", Jaurès pointed out in the public letter thanking his electors, "socialism has begun to spread into the country; it has become a friend to those who, until now, ignored or feared it." 4

The diffusion of socialist ideas among peasants who had been traditionally hostile in nineteenth century France to the ideas of reformers depended in good measure upon the quality of contacts between socialist leaders and villagers. It was in this light that Jaurès held a special place in the movement, for on the basis of both his own background and his early record in Parliament he easily qualified as a friend of the peasants.

Born of petty bourgeois stock in the small town of Castres, reared among the villagers of the Tarn, and devoid of the glossy sophistication characteristic of many urban intellectuals, Jaurès had an immediate grasp of rural life and habits. His good friend Vandervelde, the leader of Belgian socialists, once called him "a peasant of genius calibre." 5 Jaurès loved the countryside, its fields and their tenders. It was a devotion too consistent and genuine to be mistaken by peasants for a public pose. As a young student of twenty, he wrote to his friend Charles Salomon of the idyllic joy he felt during summer holidays in the Tarn, listening to "the songs of our peasants,... those chants of love and mirth..."6 And years later in the heat of political battle, he wrote with undiminished enthusiasm of his visists among the rural people in his constituency: "That friendly, personal contact with the

1 La Petite République, January 7, I 893.

2 For a discussion of the popular myth see Goldberg, Harvey, "The Myth of the French Peasant," in The American Journal of Economics and Sociology, Vol. XIII (July, I954), 363-379.

3 La Dépêche de Toulouse, January I 8, 1893.

4 Quoted by Zévaès, op. cit., 59.

5 Vandervelde, E., Souvenirs d'un militant (Paris, 1939), I60.

- A letter of August 23, 1889, quoted by Zévaès, op. cit., 23. 
robust, democratic peasantry envigorates me and increases my enthusiasm for new and expanded efforts in their behalf." 1

It was this periodic transfusion into his political life of direct contacts which separated Jaurès from that dehumanizing tendency of showing concern only for man in the abstract. Knowing men, he thought of them, rather than of ideal types. It is difficult to measure the relationship between his experience and his doctrine, but it is doubtless true that much of his central conception of justice was rooted in the scenes of his life. For as one commentator has suggested, "he knew the humble folk; he felt their pains..." 2 The peasantry of the Tarn was never uniformly or unanimously in his camp, of course $;^{3}$ cries of "à bas Jaurès!" could be heard during the bitter election campaign of 1898 when clerical forces were so active against supporters of Dreyfus. ${ }^{4}$ Yet in the top leadership of French socialism there was no other as well placed geographically to understand and sympathize with the problems of the countryside. ${ }^{5}$

During his Parliamentary initiation, which he served between I 885 and 1889 , the young Jaurès had no connection with any organized branch of socialism. But he was a strong supporter of the Republic as the key to progress and of social reform as the instrument for justice. The problems of French agriculture, which were imposing themselves on all of France in the r 880's, thus commanded his active attention.

The signs of economic distress in the French countryside were not too difficult to discern for one who represented a rural district. The symptom of the problem, the effect rather than the cause, was the decline in the proportion of rural to urban population. Thus the rural population, which had constituted 67.6 per cent of the total in 1876 ,

1 La Dépêche de Toulouse, September 9, 1897.

2 Pignatel, Fernand, in Pignatel, F., ed., Jaurès par ses contemporains (Paris, 1925), 8.

3 There was throughout the nineteenth century, and there exists even today, the strong influence in rural areas of the clergy and of landed notables. They have acted as bulwarks against social change. See the discussion of their role in Fauve, J., "Les paysans" in Duverger, ed., Partis politiques et classes sociales (Paris, x955), 174-177. See also Friedmann, G., ed., Villes et Campagnes (Paris, 1955), chap. ix.

4 Auclair, op. cit., 324-326.

5 The 1892 Inquiry into agricultural statistics revealed the following data on the Department of the Tarn: (a) of the 50,305 farm persons, 34, I32 were listed as proprietors when I 2,772 tenants, sharecroppers, and day labourers, who owned insignificant holdings, were included; 16,173 were listed as completely without land; (b) there was sharp inequality in the size of holdings: 29,566 cultivators had holdings of less than one hectare, totaling I7,6oo hectares; at the other end, only 1444 cultivators had very large holdings, covering 203,600 hectares. Conditions of this sort in the Tarn provided, of course, the most direct data for Jaurès. The statistics cited can be found in, Ministère de l'Agricole, Statistique agricole de la France, Resultats généraux de l'enquête décennale de 1892 (Paris, 1897 ). 
fell to 57.9 per cent in $1906 .{ }^{1}$ Families left the land, it could be assumed, when conditions in the city, however precarious, seemed more favorable. But central to the distress of agriculture were certain basic structural problems, which were growing progressively more serious, such as the inequality of land ownership, the heavy inroads of foreign competition, the sharp drop in agricultural prices, and the undermechanization of French farms. ${ }^{2}$

These trends were bad enough in themselves, but in the Midi, the great center of grapevine culture, they were intensified by the attack of the devastating phylloxera. Appearing first in the Gard in $186_{3}$ and spreading to the area around Bordeaux by 1867 , the dreaded vine insect was decisively felt by 1875 . "Thete is nothing in the history of agriculture", bemoaned one agricultural expert, "to compare with the disaster caused by the phylloxera $;. .$. ruination suddenly succeeded a flourishing prosperity". ${ }^{3}$ At the height of the plague, from 1878 to 1893 , much land fell worthless, unemployment took root, and villages were depopulated. The loss brought on by the phylloxera, estimated at twenty-two billion francs, ${ }^{4}$ deepened the existing plight of French agriculture.

Witness to the distress, Jaurès used his two public platforms, the forum of the Chamber of Deputies and the pages of La Dépêche de Toulouse, the highly influential republican daily of the Midi, to analyze it and to urge alleviation. Early in $\mathbf{x} 887$, as the Parliament prepared to cope with the farm problem through the usual solution of a patchwork tariff program, he chose to approach the situation differently. At the heart of the problem, he wrote, lay the question of ownership. He denied the validity of the claim that France blossomed with prosperous proprietors. He insisted instead that the tiny garden plots owned by farm workers or tenants tended to falsify the true picture available from the statistics. "Only those can truly be called proprietors, after all, who earn their entire living from the land and don't have to hire themselves out as workers in order to survive." 5

What he was trying to demonstrate, therefore, was the essential poverty of ownership which was the lot of almost half of those listed as proprietors. ${ }^{6}$ Add to them the large number of villagers who were actually listed as landless, Jaurès pointed out, and the picture was

\footnotetext{
1 Augé-Laribé, M., L’Évolution de la France agricole (Paris, I gr 2), 174.

2 Golob, E., The Méline Tariff. French Agriculture and Nationalist Economic Policy

(New York, 1944), 62-63.

3 Augé-Laribé, M., Le Problème agraire du socialisme (Paris, I 907), 89.

4 Ibid., 9r.

${ }^{5}$ La Dépêche de Toulouse, February 5, 1887.

${ }^{6}$ Loc. cit.
} 
clearer. And what was the lot of those landless, the metayers, who sharecropped the land, the fermiers, who rented it as cash tenants, and the agricultural labourers, who worked it for others at daily wages? It was indeed a hard one, and disillusioning too for peasants who had been trying for a century to achieve the promise of the French Revolution.

When Jaurès considered possible solutions, therefore, he thought less in terms of immediate but superficial measures like tariffs than of relief for what he deemed the deeper causes of distress. He wanted to bolster rural security by holding down rents for tenants and by lifting the wages of farm labour. ${ }^{1}$ He saw in the proposal to raise tariffs against foreign competition merely a shifting of the economic burden from the peasant to the worker; for a highly protected wheat supply would ultimately be the cause of a rise in the price of food. ${ }^{2}$

Such was the kind of thinking about farm problems which Jaurès was doing when he first intervened in the question in the Chamber of Deputies. On March 8, 1887, during a full-scale discussion of the proposal to raise tariffs on wheat, oats, and flour, he introduced an amendment with the vaguely stated intention of spreading around the benefits of the new duties. He proposed that the government study ways of passing along these benefits, not only to large landowners but also (and particularly) to tenants and farmhands. Thus, when farm prices went up, the gains would be shared by others through more equitable leases and higher daily wages. ${ }^{3}$

This was hardly the kind of measure that appealed to the Opportunist Ministries, which dominated French politics in the I 880's. But Jaurès persistently pressed the argument. When the moderate Paul Deschanel asserted in reply that urban workers ought to be willing to make sacrifices for their rural brothers, he shot back: "Yes, I accept that proposition, but who is the brother of the industrial laborer? Is he the capitalist, the landed proprietor? No, he is the tenant, the sharecropper, the farmhand." 4

He unmasked what he considered the deception of identifying the interests of large proprietors with those of the rest of the peasants. "Setting aside the large number of tiny holdings, gardens and vine patches, which really don't count, there is no more than one-third of the land of France which belongs to those who cultivate it with their own hands; the rest belongs to those who do not work it them-

1 Loc. cit.

${ }^{2}$ Loc, cit., January 20, 1887.

3 Jaurès, Jean, Discours parlementaires (Paris, I 904), 654.

4 Ibid., 655. 
selves." 1 The problem then revolved around the question of whether the tariffs would benefit only those who owned the farms or also those who laboured upon them. ${ }^{2}$ As a strong believer in the Republic, Jaurès concluded his presentation by urging his colleagues to create laws substantially different from those of the previous régimes: "A party cannot stand for the same things as its enemies without abdicating its position. When it begins to resemble them, it no longer resembles itself." 3

The proposed amendment of Jaurès was finally voted down by the margin of 327 to 215 . But he had accomplished at least two things through his part in the debate. He had laid down the main lines of his long investigation of agriculture, centering it around the data on rural social structure and thus drawing him close to a position most useful in the socialist movement. And he had affirmed his faith in the democratic forum, his belief that a deputy who keeps talking, manages (as one modern critic has put it) "to expose abuses which would otherwise never have been mentioned." 4

In the months that followed Jaurès tried to formulate the details of a farm program, using his standard of social justice as a yardstick. ${ }^{5}$ He fruitlessly urged reforms upon the Floquet Ministry, which was far more concerned in 1888 with the threat of Boulanger than with the plight of peasants. Among the flow of suggestions he made were proposals to lessen the financial burden of petty proprietors. Once he urged the lowering of railroad freight rates to facilitate marketing; ${ }^{6}$ frequently he returned to the striking inequities in a tax system which imposed a ro per cent levy on a peasant's land purchase and only I per cent on an heir's inheritance. ${ }^{7}$ With equal vigor he urged alleviation of pressures by private interests, who controlled the transportation system, the insurance companies, and the credit institutions. ${ }^{8}$

Jaurès measured the condition of the villagers by those standards of justice and dignity which, however vague in description, were the mainsprings of his social theory. It seemed especially distressing to him

1 Loc. cit.

2 In the 1892 statistical survey the number of proprietors, even counting those non-owners who possessed merely a tiny patch, came to 50.83 per cent of the rural population. Taking away those non-owners, one arrives essentially at the one-third figure suggested by Jaurès. These data are cited by Goldberg, op. cit., 371 .

3 Jaurès, op. cit., 657 .

4 Forster, E. M., Two Cheers for Democracy (New York, I95 I), 70.

5 See, for example, La Dépêche de Toulouse, June 18, September 3 and ro, 1887.

- Loc. cit., April 8 and August 5, 1888.

7 Loc. cit., July 7, 1889.

8 Loc. cit. 
that some men suffered dependence on others. He once reported a story which illustrated for him the difference between those who enjoyed limitless options in their daily behavior and those who were bound by their condition:

"A few months ago I was travelling with a gentleman from the West who spoke freely about his affairs. 'The spirit of insubordination and aggressiveness is spreading into the countryside. Didn't one of my tenants ask for a lowering of his rent?' And simply because he spends more than his father. The same gentleman added a little later, in a very offhand manner, that he had just lost 40,000 francs at Monaco, the equivalent of perhaps three or four years of the tenant's rent." 1

The aim of Jaurès was to assist peasants to move peacefully from the kind of dependence illustrated in the story to a new independence. ${ }^{2}$

From the republican majority he received little support. The chief remedy urged in the Chamber of Deputies was protectionism. For over a decade the drive to increase the tariffs set down in I88 I picked up strength. ${ }^{3}$ The road to success was finally clear when the industrial and agricultural interests favoring protection successfully combined to support friendly candidates in the general elections of 1889 . The prolonged debate resulted in the famous Méline Tariff of January I 2, 1892, which substantially raised the tariff rates on a broad range of products. ${ }^{4}$ But it was a measure which proved to be without substantial effect on rural depopulation, concentration of landownership, and the other major contours of the rural problem. ${ }^{5}$ Would or could socialism offer both hope and a solution?

Defeated in the elections of 1889 , Jaurès returned to Parliament in I 893. His election demonstrated that socialism could win in a primarily rural area. And it brought into the top echelon of that movement a man who had thought about agricultural problems in a direct and empirical manner. Here was an event, therefore, of considerable importance. For socialism, a movement rooted in the cities and showing a certain insensitivity to the villages, had made little political success in the early decades of the Third Republic.

1 Loc. cit., January 22, I $89 \mathrm{I}$.

2 Loc. cit., September I6, I 888.

3 Baumont, M., L'Essor industriel et l'impérialisme coloniale (Paris, 1949), 433-437.

4 Levasseur, Emile, Questions ouvrières et industrielles en France sous la IIIe République (Paris, 1907), 244-25I.

5 Golob, op. cit., $216-226$. 
Ir.

Two crucial problems confronted French socialists by $1890^{1}$ as they sought to build a large party. One had to do with recruitment, the building of a mass base, so that electoral victories might become possible. In a country where the urban population did not become a majority until well after $1914^{2}$, it was imperative to face the primary challenge of reaching and converting the French villages. The other challenge was linked to this attempt; it was the formulation of a program that was both socialist and successful, a problem for which the Marxist tradition offered rather inadequate guidance.

The necessity of enlisting rural support came increasingly to occupy the attention of French socialists, for their political organizations were different from bourgeois parties. Socialist parties had to become mass, rather than cadre parties. Whereas the latter have generally been able to depend for electoral support on élites, the former have had to find financial and political support in the masses. ${ }^{3}$ Thus, however solid their backing was among the urban workers, socialists would have to find support in rural France.

But should socialists approach peasants, many of whom possessed at least a little rural property, with their doctrine of collectivism? Could the promise of the nationalization of land be effective among men whose dream was likely to be more land? Marx himself offered little practical guidance to socialists. In the Communist Manifesto he had called for nationalization of land, believing it both inevitable and economically desirable that small, inefficient property should disappear. ${ }^{4}$ In Capital he neglected to analyze agricultural production in detail on the general assumption that the general laws of capitalist development applied also to the land. ${ }^{5}$ His followers, frequently satisfied to recast his words rather than to gather concrete evidence, continued to predict the end of small property and the pauperization of the peasantry. Writing in this vein in Collectivisme et révolution (1879), Jules Guesde, the leading doctrinaire Marxist in France, forecast the swift and inevitable disappearance of petty proprietors in the face of capitalistic encroachments. ${ }^{6}$

1 French socialism achieved no unity until I 905 . In 1890 there were seven distinct groups. Auclair, op. cit., 194 .

${ }^{2}$ Friedmann, op. cit., 9 .

${ }^{3}$ For a lucid discussion of the difference between mass and cadre parties, see Duverger, Maurice, Political Parties (London, 1954), 62-7r.

4 Augé-Laribé, M., Petite ou grande proprieté? (Montpellier, 1902), 122-1 25.

5 Augé-Laribé, M., Le Problème agraire du socialisme (Paris, 1907), 8-9.

6 Augé-Laribé, Petite..., op. cit., I 27. 
The Marxist line was laid down in France at the Congress of Le Hâvre, held in 1880 by the newly founded Parti outurier français (P.O.F.). The program there adopted had been worked out by Guesde and Lafargue with the active help of Marx and Engels. On the question of agriculture the resolution adopted by the Congress called for "the collective ownership of land, ores, and farm machinery as quickly as possible." ${ }^{1}$ Such a program, lacking either in immediate relief for or in careful analysis of the rural areas, was hardly a successful instrument for winning the countryside. After a decade of poor electoral results. for the socialists, careful reconsideration of their program was in order.

The P.O.F. had devoted its attention at the 1891 Congress of Lyon to the question of municipal elections, and so profitable had this proved that in the elections of May I, I 892, some thirty-six municipalities returned socialist majorities. At its Congress of Marseilles, held in September, I892, the P.O.F. therefore turned to the problem of spreading socialism into the countryside. The Marseilles program on agriculture, reiterated at Nantes in 1894 , listed among its eighteen articles a series of reforms, some of which were already part of the Radical platform. For the landless agricultural workers, they included minimum wages, set by their own unions and the municipal councils, and retirement pensions for the sick and aged, established through a tax on large landowners; for the small peasants, they called for cooperatives to purchase machinery and fertilizer, cheap credit, lower freight rates, the spread of agricultural education, and, for the metayers and fermiers, more favorable leases, set by arbitration commissions. ${ }^{2}$

This was sheer reformism, designed to win votes for socialism. But whether it was truly a socialist program, whether it presented a needless barrier to ultimate collectivism, was another question, one that was then facing the socialists in several countries. The Marseilles program thus set off a lively debate, which reached a high point in November, 1894, when Engels himself intervened with an article in the pages of the German organ, Neue Zeit. ${ }^{3}$ The prestige of Marx's collaborator was sufficient to give his words an especially heavy weight. When he lined up, therefore, in opposition to the proposals of the Parti ouvrier frangais, he placed French socialists on the defensive.

Engels regarded the evolutionary course of the European peasantry in this way: "The development of the capitalist form of production has struck the fatal blow at small agrarian property. It is declining and

1 Augé-Laribé, Le Problème..., op. cit., 9.

2 Lafargue, P., Programme agricole du parti ouvrier français (Lille, 1897), 1-4.

3 The most tecent French version is Engels, F., "La Question paysanne en France et en Allemagne," in Cahiers du Communisme, Vol. 31 (November, 1955), 1467-1488. 
will inevitably disappear." 1 Those who purported to be the defenders of the small peasants, urging tariffs as relief measures, were really selfinterested large landowners: "The competition of North and South America as well as India has flooded the European market with foodstuffs so cheap that native producers can't compete. The large and small landowners are both threatened. And so, the large proprietor poses as the champion of the small and the latter accepts him as such."'2 Socialists then ought not add to the deception by implying that small peasant holdings could be saved.

Engels recognized the need for some kind of attractive message if socialists were to win strength politically. But the French program was guilty of at least two serious errors, Engels charged, one of theory and the other of tactics. "They ask socialism to aid the peasants in possession of their small plots of land after having affirmed that this kind of property is destined to disappear." 3 And if the deisre to protect the small peasant sprang merely from the desire to win his vote, then, he pointed out, the socialists were making a tactical error. "We will never make a socialist of the peasant who asks us to protect his petty property, any more than of the small employer who wants to remain an employer." 4

What Engels proposed was greater consistency and integrity in the position of the socialists. They ought to assume primarily the job of explaining why and how the peasants were falling prey to outside forces. They could then offer the only genuine socialist hope, that of working toward collective property in which small landowners and landless alike would have a stake. ${ }^{5}$ Whether they could win on such a program was a question Engels did not discuss. Thus the problem of relating peasants to collectivism, so fundamental in large areas of the world since the Russian Revolution, was undergoing here a kind of embryonic examination.

Socialist publicists beyond and within the borders of France moved into the debate, and their greatest weight fell on the side of Engels. Domela Nieuwenhuis, the fiery Dutch socialist who constantly warned early congresses of the Second International against political opportunism, considered the French program a crass device for winning the support of an anti-socialist peasantry. ${ }^{6}$ The most prolific Marxist

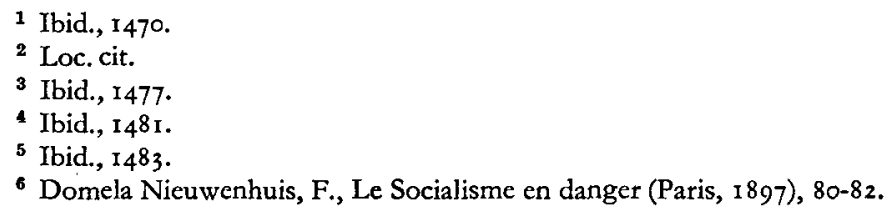


of the period, Karl Kautsky, wrote bluntly that "a socialist agricultural program for the protection of the peasants would be not only useless but completely erroneous." " But in an example of the kind of sophistry to which Marxists at times resorted in bringing dogma and practice together, Kautsky then set down in detail "the measures by which we can prepare the agriculture of today for the socialist mode of production..." 2 What followed were proposals for social security, education, and cheap credit not too different from the Marseilles resolutions. ${ }^{3}$ The Italian Gatti, in whose country collectivists also faced a rural majority, sided in theory with Engels, but took a less intransigent position. Though he considered a reform program to save small property as political opportunism ${ }^{4}$ he advocated cooperatives as a valid means for simultaneously relieving the peasants and preparing them for socialism. ${ }^{5}$

Among French socialists the group centered around the militant printer, Jean Allemane, was most critical of trying to cater to the small peasants. Reacting strongly against the compromises demanded by daily politics, the Allemanists repeated the widely-heard accusation that the preservation of private ownership in land might win votes but would never produce socialism. ${ }^{6}$

To bring some stability into the fluid state of socialist theory on agriculture, the London Congress of the Second International devoted its fifth session on July 30 , I 896 , to passing definitive resolutions on the problem. The report of the Committee on Agriculture began in the best tradition of socialist rhetoric:

"The evils which capitalistic exploitation, including landlordism, produce alike for the cultivator of the soil as for the whole of society at an ever increasing rate, can be definitively abolished only in a society in which land, like the other means of production, has become socialized." 7

But at the very brink of concrete proposals, the report made an admission which left the problem as unresolved as ever:

1 Kautsky, Karl, La Politique agraire du parti socialiste (Paris, I 903), 29.

2 Ibid., 32.

3 Ibid., $54^{-213}$. The same equivocation is in Vandervelde, E., "Le Socialisme et la transformation capitaliste de l'agriculture," in La Révue socialiste, Vol. 3 I (June, I90I), 64I-66I.

4 Gatti, G., Le Socialisme et l'agriculture (Paris, 1901), 266-268.

5 Ibid., 334.

${ }^{6}$ Le Parti Ouvrier, February 16 and September 21, 1895. Note also the scathing remarks by the philosopher of revolutionary syndicalism, Georges Sorel, in his preface to Pelloutier, Fernand, Histoire des bourses du travail (Paris, I 902), 14-15.

7 International Socialist Workers and Trade Union Congress, Report of Proceedings (London, 1896), 25. 
"The conditions of land tenure and the division of classes among the agricultural population in different countries are, however, too various for it to be possible to formulate a program which shall be binding for the labor parties of all countries as regards the means for attaining this end or the particular classes to be won over.". 1

In the lively discussion that followed, led by Vandervelde and Lafargue, the wisdom of such a resolution was compared with the folly of trying to make a policy universally applicable. ${ }^{2}$ The motion of the commission was then passed unanimously.

So it was that socialists, especially the Marxists, were caught in a vise. Devoted to collectivism, they balked at defending property, even small peasant property. Tied to a deterministic theory of history, they were convinced of the futility of trying to stay the inevitable disappearance of peasant holdings. But in a country like France contact with the village was essential to success. And then, in the bone of socialism was supposed to lie the marrow of sympathy. How could socialists ignore misery, wherever it existed?

Jaurès was far less hampered than his Marxist friends in the P.O.F. by the confines of dialectical materialism. Guesde and Lafargue had changed tactics on the agrarian question in 1892 , but the shift was so abrupt that they were easily accused of merely adjusting to electoral needs. The mainsprings of socialism were significantly different for Jaurès. As much as he appreciated the contribution of Marx, he was an idealist, for whom the motivation in socialism was the quest for justice. ${ }^{3}$ Sprung from such a tradition, he could neither ignore the plight of the needy nor accept abstractions about men among whom he had lived. Thus, while a mass of doctrinal clichés filled the air, Jaurès gave socialism a stake in analyzing and proposing solutions for rural problems.

III.

The critics of socialism made capital of what seemed to be theoretical contradictions. How, they asked, could socialists preach collective property to urban workers while defending the property of peasants? Jaurès tried to answer the charges, and in so doing he divorced

1 Ibid., 26.

2 Ibid., 28-29.

${ }^{3}$ The idealism of Jaurès, differentiating him from Marxism, is best brought out in his famous debate with Lafargue. See Jaurès, Jean, et Lafargue, Paul, Idéalisme et matérialisme dans la conception de l'histoire (Paris, 1895). 
socialism from rigid dogma. "Those profound philosophers of capitalism have been duped by words! Socialism has no systematic preference for one or another way of organizing labour." The criterion of judgment, he pointed out, speaking actually more for himself than for the entire movement, was the degree of independence a given type of economic organization yielded to the workers. ${ }^{1}$

Perhaps stung by the criticism, however, Jaurès tried to define the meaning of collectivism as it applied to the land. It proposed to ensure to all those who worked the land a fair and full return for their labour. ${ }^{2}$ He then repeated his familiar program of decent wages for farm workers, relief from unfavorable leases for tenants and sharecroppers, and cheap credit for small owners. ${ }^{3}$ What he sought to ensure was "the right of all citizens to the fruits of their labor, to their legitimate property, and to a decent living." 4

Le Temps, the great Parisian organ of moderate republicanism, attacked this position as a piece of duplicity to win rural votes, charging that under collectivism only the state would be a proprietor. ${ }^{5} \mathrm{Re}$ sponding that Le Temps was engaging in vulgar oversimplification in its identification of collectivism with primitive tribal communism, Jaurès reiterated that socialism was not static but adaptive. Its moral center remained the same, but the institutions through which it expressed itself frequently changed. ${ }^{6}$

Once he returned to the Chamber as a socialist in 1893 , he spoke often in favor of agrarian reforms. As unofficial spokesman for the socialists, he made concrete proposals and helped to answer the charges of negative sterility frequently aimed at socialist attacks. $\mathrm{He}$ intervened, for example, in the discussion of the budget for 1894 and urged a shift in the tax burden by replacing part of the land tax with a progressive inheritance tax. ${ }^{7}$ Though unsuccessful, he rose again, on January 16, 1894, to present another extended criticism of the tariff as the answer to agrarian distress.

It was at the time that the tariff commission, headed by the archprotectionist Méline, was proposing once more to raise the duties on foreign, especially Russian, wheat. Jaurès introduced a counterproposal, co-sponsored by such socialists as Millerand, Viviani, Sembat, and Vaillant, which would have made the state the sole

1 La Dépêche de Toulouse, January II, 1893.

2 Loc. cit., October I8, I 893.

3 Loc. cit.

4 Loc. cit., October 23, 1893 .

5 Le Temps, October 5 and $28,1893$.

${ }^{6} \mathrm{La}$ Dépêche de Toulouse, October 30, 1893.

7 Journal Official, Chambre des Députés, June I 5, I 893. 
importer of foreign wheat and flour. The aims of the proposal were the elimination of private grain speculators, whom he accused of engrossing quantities of grain cheaply to be marketed dearly at times of relative shortage, and the regulation of the price of foreign supplies to prevent highly depressing effects on domestic prices. ${ }^{1} \mathrm{He}$ thus took his stand against protectionists, who sought to cut off outside supplies, thereby raising prices to urban workers, and the equally doctrinaire free traders, who would have let in unlimited outside supplies, whatever the effects on domestic prices. "The crisis in prices, which lowers the income of the large, absentee landowners, simultaneously brings ruin to the small proprietors; it brings ruin to the tenants who made their leases at the time of higher wheat prices; it brings ruin to sharecroppers, who have no income except from the price of their products." 2 Calling both positions too doctrinaire, he sought a policy to reconcile the opposing interests of peasants, who needed good prices, and workers, who needed cheap food. ${ }^{3}$

The criticisms of the proposal were numerous. Charged with advocating a huge new monopoly, Jaurès distinguished between a monopoly belonging to the community and one owned by a privileged capitalist. Attacked for establishing a great new source of bureaucracy, he noted in the same vein the difference between a bureaucracy put to public uses and the private bureaucracy of industry, devoted to selfish ends. As the debate wore on, Jules Roche, sincere economic liberal, accused him of that ultimate heresy of trying to repeal natural economic laws. Strongly attracted to the nineteenth century theory of evolution, Jaurès answered by rejecting the concept of society as a mechanism.

"A new law, which is the key discovery of our century, which is the great insight of our contemporary science, a law which is the law of all laws, is the law of evolution... It is the idea that neither nature, nor life, nor humanity are chained down to immutable forms... We [socialists] simply want to apply this universal law of evolution." 4

This particular attempt at application, however, was decisively defeated, $48 \mathrm{I}$ to 52 , and a tariff increase on wheat carried the day.

1 Loc. cit., Janaury I6, 1894 .

2 Loc. cit. Jaurès named as great merchants in the grain speculation the houses of Ephrussi, Thalmann, and Dreyfus. See La Dépêche de Toulouse February 27, I894.

3 The same desire to go beyond regional and special interests, which marked his approach to the tariff question, moved Jaurès in the debate on the alcohol tax. In the midst of the tug-of-war between distillers and vineyard owners, he proposed a state monopoly of the distinlling of spirits. Sce Journal Officiel, Chambre des Députés, June 8, 1895 .

4 Loc. cit., January 20, 1894. 
Foreshadowing their great duel between 1896 and $1898^{1}$, Méline clashed frequently with Jaurès on the agrarian question. The future Premier accused the socialist of preparing the ruin of agriculture by advocating the nationalization of land, an accusation warmly supported by Le Temps. ${ }^{2}$ Such criticisms led Jaurès to outline very concretely the measures his party was proposing for rural amelioration. Tax relief was a pressing need, but it could be achieved only by shifting the fiscal burden to progressive income and inheritance taxes. Cheap credit would become possible, he insisted, only after the socialist measure of nationalizing the dominant Bank of France. Far from preparing the depopulation of the villages with such moves, the socialists aimed "to hold them [the peasants] on the land by... ensuring that they work for themselves and not for absentee landlords living in the big cities." 3

But the charge that the socialists wanted immediate nationalization of the land died hard. Hostile critics found it convenient to recall the abrupt shift in the line of the P.O.F. ${ }^{4}$ But when they tried to accuse Jaurès of the same deception ${ }^{5}$, the critics were on unsafe ground. $\mathrm{He}$ believed, of course, that the trend in agriculture, as in industry and commerce, was toward concentration. "In the Cher, the Nièvre, the Allier," he wrote, "large holdings are being formed; there are entire parishes which belong to two or three men..." 6 He believed that trend to be inevitable. But Jaurès was far too concrete and humane to let the issue rest there. However short-range his help might be, he could hardly have advocated tearing the plots from beneath peasants for whom he had such deep sympathy. Of course, he could not convince all the peasants, even of his own constituency, that he was really sincere. ${ }^{7}$ But his association with the countryside probably went further in pushing socialism into the villages than the polished rhetoric of many of his colleagues.

The high point in the Parliamentary campaign waged by Jaurès for agricultural reform came in an extended intervention, occupying three entire sessions in the summer of 1897 . So impressive a campaign did this represent, so much did it sum up the extent of socialist concern for the peasant, that its three parts were brought together in an oftreprinted brochure, Socialisme et paysans. ${ }^{8}$

1 Jaurès was a constant critic of the conservative Méline Ministry, 1 896-1898.

2 Le Temps, October 29, I894.

3 Journal Officiel, Chambre des Députés, October 27, 1894.

${ }^{4}$ Le Temps, July 29, 1893.

5 Le Telégramme, November 23, 1895.

6 La Dépêche de Toulouse, April 24, 1894.

7 Auclair, op. cit., 324-325.

8 It was first printed in Paris in 1897. 
It was on December 14, I 896, that Jaurès first gave notice of his intention to interpellate the Méline Ministry on its agricultural policy. But the Ministry, enjoying power since April 29, 1896, when the Radical Bourgeois government fell, placed Jaurès on the agenda only months later, on June 19, 1897. Méline was himself Minister of Agriculture, a conservative on property questions, a high protectionist on tariff matters, and a bitter critic of the socialists (who had dubbed him "Méline-pain-cher"). ${ }^{1}$ By the time the forum was finally and reluctantly turned over to him, Jaurès had had time for even more than his usual amount of extensive preparation.

He spoke at once of the assumption that most of the countryside was tilled by prosperous, independent peasant landowners. He called off the roll of 3.5 million farm workers, 800,000 tenants, and 500,000 sharecroppers, all of whom were excluded from ownership. ${ }^{2}$ The more fortunate workers were earning 350 francs a year while working oppressively long hours and suffering the constant threat of technological unemployment. ${ }^{3}$ Both métayers and fermiers complained that they were not reimbursed for improvements they made on the farms. And all of these rural types were gradually losing hope of becoming landowners. Jaurès answered such defenders of the present agrarian regime as Méline, Guyot, and Deschanel when he cited the 1882 report on landholding. It demonstrated to him the trend toward concentration of ownership, an inescapable conclusion when faced with the fact that 28,000 proprietors owned as much as six million others. ${ }^{4} \mathrm{He}$ brought into the debate also the views of the widely known economist Leroy-Beaulieu, who, he charged, considered the

1 Chastenet, Jacques, Histoire de la IIIe République, 3 vols. (Paris, I95 2-1955), III, 92-93. The journalist Maurice Allard, referring to the long delay in granting Jaurès the forum, said: "It is obvious that the Premier had a special interest in stiflying the discussion..." La Lanterne, November 7,1897 .

2 Journal Officiel, Chambre des Députés, June 19, I 897.

3 The very recent work by Chastenet places the day labourer's annual wage in 1906, when conditions had improved, at 600 francs for men and 400 for women. Op. cit., 343.

- A completely rigorous accounting of the agricultural data, devoid of any propaganda content, would have had to cope with other matters. There is the question of what a large or small property is, the answer to which frequently hinges on fertility and the nature of the crop. A tiny holding in vines, fruit, or vegetables means more, for example, than one in wheat. Furthermore, using the same data, Chastenet concluded (ibid., 342): "A comparison of statistics indicates progress for small and medium property at the expense of large (more than four hectares) and very small (less than one hectare)..." But he reveals neither the actual number of hectares in large and small holdings nor his reason for making his small, medium, and large categories so different from the ones in use in official statistics. The insinuation of Jaurès that independent peasant holdings were going to disappear, however, has not to date been validated. A very recent study of contemporary agriculture concludes thus: "...the number of medium holdings tends to increase at the expense of very small and very large holdings." Fauvet, op. cit., I $6_{3}$. 
disapperance of small, inefficient owners both inevitable and desirable for economic progress. ${ }^{1}$ Jaurès was, of course, implying that bourgeois theorists, who had consistently attacked the socialist threat to private property, were themselves referring to its alteration without conspicuous regret.

But how did Jaurès aim to cope with the very immediate threat of foreign competition? Repeating his often-heard attacks on the tariff solution, ${ }^{2}$ he urged instead reduction of financial burdens on small peasants, helping them to find capital for land improvement by which they could better compete. This was possible only by removing some pressure, public and private, which dissipated their income and forced them into technological backwardness. He exposed particularly the role of the great processors, powerful enough to force down prices paid to the small producers. Sugar refiners, already beneficiaries of a government subsidy to meet foreign competition, were nevertheless threatening further price reductions to sugar-beet farmers; the big millers, who were progressively driving out small, indepedent competitors, were acting as a syndicate of speculators determining the price paid for wheat; at Roquefort, where there had been great competition among the small cheese factories, a large, impersonal company had come to dominate and to force down the price of milk from Aveyron. ${ }^{3}$ His solution lay in the nationalization of the processing industries.

To treat an agricultural problem as structurally complex as the one Jaures had outlined, what kind of program could he suggest that would be immediately helpful and ultimately useful? The long-range socialist goals he set out as the increase of production to raise consumption and the transformation of property to ensure universal security. But the path toward these general objectives had to be marked by those many concrete reforms, which had constituted the socialist rural program since the Congress of Marseilles.

The criticism of Engels and others in the Second International was sufficiently disturbing to require a public response. And Jaurès answered out of his considerably less dogmatic reading of socialism. "To that argument we say... that between large landholding and small there is not only a quantitative difference, but in some measure a qualitative one; the former is an expression of capital, the latter of labor." 4 Refusing to blueprint the dimensions of a new property order

1 Journal Officiel, Chambre des Députés, June 26, 1897.

2 Loc. cit.

${ }^{3}$ Loc. cit. Note his further discussion of the "Société de Roquefort" in La Dépêche de Toulousc, September 23, I897.

4 Journal Officiel, Chambre des Députés, June 26, I 897. 
(as Marxists were prone to do), he concluded his extended interpellation instead by stating the most important touchstone for a democratic land system - that "the nation maintain its sovereign right over the means of production to prevent any single individual form usurping part of the property that should belong to all who work." 1 Bluntly put, Jaurès had declared that small, individually owned farms could fit into socialism, a position much closer to Proudhon than to Marx.

In and out of the Chamber Jaurès was challenged by his opponents both for his facts and his interpretations. Paul Deschanel replied for the Ministry and denied a real conflict of interest between large and small landowners; in fact, he urged them to form mutal aid societies to solve their common problems. ${ }^{2}$ Jules Méline, speaking on July 4, 1897, at Vesaul, insisted that small proprietorship was on the increase while accusing the socialists, despite the position of Jaurès, of proposing immediate nationalization of land..$^{3}$

The most extensive reply came from Leroy-Beaulieu, the economist cited as predicting the end of small property. Composing an entire brochure in hostile reply, he sought to show that socialists "have no scruples about mutilating and falsifying the teachings and theories of their opponents." " Correcting the misquotations of his work by Jaurès, he referred readers to the long discussion on agriculture in his Traité d'économie politıque, where he admitted the technical advantages of large property, but concluded that "large and small holdings can coexist, get on well together, and be of service to each other." 5

Jaurès checked the texts of his protagonist and admitted error in using his own summary as direct quotation. He promised to make the correction. "I don't want anyone to say that a socialist would alter even the slightest shading of an opponent's thought; and since it was in the Chamber that this error, however slight, was committed, it is in the Chamber that I will rectify it when the debate on the agricultural question is resumed." 6 Jaurès continued to hold, however, that though the words were different, Leroy-Beaulieu's meaning was exactly as he had interpreted it before - that the elimination of small by large landholding was inevitable and progressive. ${ }^{7}$

1 Loc. cit., July 3, 1897. See the resemblance to Proudhon's thought in Maitron, Jean, Histoire du mouvement anarchiste en France (Paris, I95 I), 29.

2 Augé-Laribé, Petite..., op. cit., I 4 I.

${ }^{3}$ Le Temps, July 6, 1897.

${ }^{4}$ Leroy-Beaulieu, Paul, Les Citations de M. Jaurès et la veracité des socialistes (Paris, I 897$), x$.

5 Ibid., 7-8.

${ }^{6}$ La Petite République, July 3 1, I 897.

7 Loc. cit., September I I, 1897 . 
The Chamber voted on July 3, 1897, after the three long sessions devoted to the Jaurès address. His motion asking "the government to organize a public inquiry into the state of agriculture and rural property and into the condition of farm workers" was rejected in favor of Deschanel's mild declaration favoring individual over collective property. ${ }^{1}$ But the exposition was not without its stirring effects. It so disturbed the confidence of the government that Méline himself felt called upon to finish the debate on November 13 and 20 , parading for the public all of his familiar arguments on the stability of the peasants and the duplicity of the socialists. ${ }^{2}$

Actually, the formulation by Jaurès was something of a compromise between theory and reality, between present difficulties and eventual socialism. Measures like consumer cooperatives, farm workers' unions, and nationalization of processing industries were formulated with both the now and the then in mind. From such measures he hoped to strengthen the individual and form the collectivist conscience.

IV.

Jaurès became the socialist champion of the peasant neither by careful design nor by original doctrinal contribution. It was a position he assumed almost spontaneously through his background and his disdain for tigid oversimplification. He had three main qualifications for the role. First, he had the heavy accent and the robust frame of the tarnois; he was, in short, recognizable as a man of the rural Midi rather than as a highly polished Parisian. Secondly, he was not confined tightly within the dogmatic framework of Marxism. Jaurès did stress, to be sure, the principle of progressive concentration. And his ready acceptance of this economic law led him into the weaknesses of exaggeration and contradiction. Thus, the inevitable disappearance of small property has yet to be proved, as recent studies of French agriculture indicate. ${ }^{3}$ The tendency is still present ${ }^{4}$, but its development has been slow. In addition, by framing the problem in terms of inevitability while promoting a concrete reform program, Jaurès was

1 Journal Officiel, Chambre des Députés, July 3, 1897 .

2 Loc. cit., November 13 and 20,1897 . The release of the 1892 agricultural statistics in 1897 actually vindicated Jaurès in showing a decline of 138,000 proprietors from 1882 to 1892. La Lanterne, November 7, 1897.

3 See Augé-Laribé, M., Situation de l'agriculture française, I930-1939 (Paris, 1945), 29: "France is certainly a country where small and medium holdings predominate."

4 Note the figures for increase of tenancy and sharecropping, 1929-1946, in Fauchon, Jean, Économie de l'agriculture française (Paris, 1954), 43. 
caught in the methodological weakness of most of reformist socialism. ${ }^{1}$ But he rather consistently vaulted over dogma to advocate an empirical program that satisfied his ideal of justice.

Finally, he gave his socialism a moral fervor, which no so-called scientific formulation could match. In reducing the agrarian problem to its component parts, he was able to reveal the special difficulties that beset many landed types. In formulating for them a program of relief, he illustrated the premise that socialism stood for a better life. ${ }^{2}$

The exact degree to which Jaurès helped socialist success in the villages is impossible to evaluate. He himself won elections, except in I 889 and 1898 , in a primarily rural area. Beyond that, socialism was making headway in the countryside by offering practical reforms. From the Congress of Limoges in 1906 to the Congress of Saint-Quentin in I9I I, the unified Socialist Party emphasized its respect for the private property of the peasants. ${ }^{3}$ And its successes were at least enough to frighten the opposition 4 and to lay the groundwork for later and greater socialist strength in rural areas. ${ }^{5}$

1 The best criticism of the dualism between determinism and voluntarism has been made by Drachkovitch, M., De Karl Marx à Leon Blum (Geneva, 1954), passim.

2 On the greater appeal of moral socialism than rational Marxism, see Man, Henri de, The Psychology of Socialism (New York, 1927), passim.

${ }^{3}$ Compère-Morel, A., Le Socialisme et la terre (Paris, 1928), 20-21.

4 On the growth of socialism in the countryside, see Compère-Morcl, A., La Petite proprieté paysanne et le socialisme (Paris, I 926), passim. For a typical reaction of fear over the spread of socialism in countryside, see Journal des Débats, October 12, 1894.

${ }^{5}$ For recent socialist strength in rural areas, see Rimbert, Picrre, "Le Parti Socialiste" in Duverger, ed., Partis Politiques et..., op. cit., 204-207. 